\title{
ANALYSIS OF THE EXTERNAL FACTORS' IMPACT ON ACCOUNTING (FINANCIAL) REPORTING: THE EDUCATIONAL ASPECT
}

\author{
Tatiana Borisovna Turishcheva ${ }^{1^{\star}}$ and Irina Vladimirovna Kirillova ${ }^{2}$
}

\author{
${ }^{1}$ Associate Prof., Plekhanov Russian University of Economics, assistant prof. Financial University \\ under the Government of the Russian Federation, Russian Federation, ttb2812@mail.ru \\ ${ }^{2}$ SME, Financial University under the Government of the Russian Federation, Russia, \\ 01042000m@mail.ru \\ *Corresponding Author
}

\begin{abstract}
As an array of external factors render instability to the current economic and financial situation, preparation of the accounting (financial) reports have undergone significant alterations. The spread of COVID-19 was of the strongest influence on financial reporting by shifting the deadlines of the reports and breaking one of the key accounting principles - the sustainability principle and exacerbating the post-reporting events disclosure problem. The current events also encumber realistic assessment of financial stability of a company by creating significant market and credit risks. The epidemiologic situation, the falling energy prices and the dollar growth are of a direct influence on the accounting report structure by inflating such an indicator as accounts receivable. Since operations are suspended, and the revenue and net profit fall, the companies are unable to pay their employees, to the budget and extra budgetary funds as well as other counteragents on time. A lower net profit reflected in financial reports hurts the investment attractiveness of many local companies. The accounting forms also reflect changes in cash flows and obligations of a company necessary for economic analysis. Economic uncertainty and stagnation mean that accounting (financial) reporting is necessary both for the internal users of information to make effective managerial decisions and for the external users, including investors, to analyze the investment potential and possible investment of funds important for the organization as well as for banks to analyze the possibility of credit repayment. This is why our research will help to account for all the aspects while preparing and forming a financial report in education.
\end{abstract}

Keywords: accounting (financial) reporting, education, COVID-19

\section{INTRODUCTION}

The modern economic life after a stock market crash and the Covid-19 pandemic have a great influence on the Russian economy, especially on business management and accounting. This is the first time in many years that systematized and generalized information about economic activities of many companies in the form of an accounting (financial) report is presented in a new regime and with heavy losses (Aaronson, 2007, p. 5; Anantharaman, 2017, p. 1261). 
The lockdown regime suspended production of goods, services and works pushing business activity and management efficiency indicators down. This is why the current financial accounts are conspicuous for a lower value of net assets and net profit, decreasing deductions to reserves and the impossibility to cover losses from them (De George, 2016, p. 898). Financial reporting should be done taking into account all external and internal factors, for which we have to realize all economic consequences and make effective managerial decisions.

\section{THEORETICAL BACKGROUND}

\subsection{The Accounting Elements that Have Undergone Changes}

The most important EXTERNAL factor for the accounting (financial) reporting was coronavirus Covid-19. It did not only shift the reporting deadlines, but also questioned accuracy of accounting in general.

\subsubsection{Business Continuity Assumption}

The restrictive measures imposed by the government dealt a severe blow to one of the accounting principles accepted by the International Auditing Standards (IAS) 570 Continuity of Operations introduced in the Russian Federation by a Finance Ministry order dated January 9, 2019. The principle is based on an assumption that organization's operations are and will be continuous in the future. However, far from all organizations will able to continue their operations for the next 12 months (Voronova, 2020, p. 2). An accounting (financial) report is to be based on an assumption of business continuity except when there is no other alternative but to cease activities or undergo intentional liquidation. In accordance with i. 20 of Russian Accounting Rules $1 / 2008$, if there is doubt about the use of the continuity principle, the organization should describe the reason behind the uncertainty, which measures are taken to remove it and how it will impact the company's operations (Gorlanov, 2019, p. 5293).

A company, which doubts its business continuity due to the epidemiological situation in the country should first of all assess the influence of Covid-19 on its operations (Petrov, 2020, p. 119), including analysis of interruptions of its operations, the terms and conditions of agreements with the counteragents and the possibility of their debt repayment, the impact of the external factors on liquidity and working capital, the possibility of debt repayment from equity without raising debt and disclose the new data in an accounting report (Morozova, 2020, p. 2196; Ternovykh, 2020).

\subsubsection{Post-Reporting Events in Accounting and Reporting}

According to Russian Accounting Rules 7/98, a post-reporting event is an operational event, which exerted or can exert influence on the financial state, cash flows or reporting results of an organization and which occurred between the reporting date and the date of signing of an accounting report for the reporting year. The quarantine, according to (Akhmadeev, 2019, p. 1197; Korableva, 2019, p. 26), was of a significant influence on reflection of the events and assessment of the financial consequences (Avvakumova, 2020, p. 533). The organizations, which will have to adjust their reporting, are primarily the hotel and touristic businesses, public catering, retail and many others. These companies must adjust their reporting, because the events were significant for their operational activity and decisions made by the users of the reports, including managers' decisions to issue securities and pay dividends. Since the restrictive measures triggered suspension of activities, depressed demand for goods and services and made raising debt difficult, explanatory notes to the report should outline the events and mention a monetary assessment of their consequences (Barbu, 2010, p. 220; Golubtsova, 2019, p. 785).

\subsubsection{The Deadline and Format of Reporting}

In accordance with the Federal Tax Service of Russia's order dated November 13, 2019 №MMB-7-1/570@ On Approval of Formats of Submission of a Copy of Preparation of Annual Accounting (Financial Statements) and the Auditor's Report in the Form of Electronic Documents for the Purpose of Forming the State Information Resource of Accounting Financial Statements, reporting is filed electronically to the tax body at the location of an economic entity. Besides, in accordance with article 18, the State Information Resource of Accounting (Financial) Reporting (as amended by Federal Law dated November 28, 2018 №444-F (as amended on July 26, 2019)), an economic entity must provide a copy of an annual accounting (financial) report (further an obligatory report copy) to the tax body at the location of an economic entity to form a state information resource. If the current external factors have an adjusting influence on accounting (financial) reporting, the adjusted report is provided no later than in 10 working days after the day of adjustment or the day of approval of the accounting (financial) report. The deadline for providing an adjusted report for limited liability companies is 10 working days after April 30, for joint stock companies 10 working 
days after June 30, 2020 respectively.

\subsubsection{Other Consequences}

The other fallout of the pandemic on financial reporting is the current rules of the International Financial Accounting Standards (IFRS). The quarantine imposed by the government were of a strong effect on IAS 36 asset depreciation, a standard describing a fall in the value of an asset, which exceeds a planned decrease due to physical or functional depreciation (Petrova, 2019, p. 263). A company, which has discovered a trend for depreciating assets should first of all check its property for depreciation with the help of analysis of expected cash flows from the asset (Kevorkova, 2020, p. 128).

The unstable energy market and the spread of the new virus impacted not only operations of companies, but also the market. Many companies' sales plummeted by more than $20 \%$, customers are often unable to pay their debt. As a result, the credit loss on financial assets turned out to be much higher than expected. The industries with heavy receivables, which were most hit by the external factors, should build their ECL model to establish the expected credit loss from overdue accounts receivable (Singleton-Green, 2014, p. 697).

On top of the aforementioned factors, changes in provisions connected primarily with the revealed losses of agreements and restructuring of operations on the back of economic uncertainty will also have an impact on financial reporting. Changes in the schedule of lease payments will incur changes in lease accounting, unplanned stocks at warehouses and delivery failures under contracts will lead to changes in the assessment of stock under (IAS) 2 (Zvereva, 2020, p. 44).

\subsection{Data Analysis}

\subsubsection{Impact on the Balance Sheet}

The articles of the second section Working Assets are most susceptible to significant changes. A slump in cash and its equivalents triggered by suspension of operations due to the lockdown regime and ruble devaluation coupled with heavy receivables will lead to significant problems with stable solvency, financial instability and dependence of a company on external sources of financing. Heavy stocks coupled with restricted sales will translate into overstocking and breaking the rhythm of production (Maltseva, 2020, p. 347).

A lower share of equity in total capital will exacerbate the company's dependence on raised capital. A lower return on equity will scare off potential investors from investing in the industries, which suffered from the external effects. Rising short and long-term liabilities coupled with falling sales can have a most negative effect on the financial stability of an organization. Unpaid credits and loans, overdue payables may become sustainable and entail bankruptcy.

On the whole, a lot of companies will end the reporting year with a shrinking grand total in absolute terms. This trend points to a slowing economy, insolvency on the back of falling demand, overdue receivables and payables, sales restrictions, etc.

\subsection{Impact on the Statement of Financial Results}

The restrictive measures dealt a heavy blow to the economic indicators of many companies. Revenue of fitness centres, retail, entertainment fell by over $90 \%$. A full list of affected industries is in the Government's regulation dated April 3, 2020 № 434. A slump in revenue caused by plummeting demand and the impossibility of sales translates into the absence of own funds in circulation and the impossibility to stay in the market for a long time. Lower revenues mean a consistent fall in the gross profit and sales profit.

The affected firms will have to become active in promoting their products through social networks with the help of marketing campaigns to recover the indicators of yore. A creative concept will help outline competitive advantages, boost the company's revenue and as a consequence the net profit. This trend of falling net profit, i.e. net earnings after costs will reduce provisions to reserve capital necessary to cover losses, diminish dividends and lead to investor outflow. This will create the danger of company liquidation because of a lack of financing.

\section{RESULTS}

Adjustment of financial reports to take into account foreign factors' influence, including the coronavirus Covid-19 spread, the failure of the OPEC+ deal and the currency rate fall helps us assess the current economic situation of a company correctly, analyze the connection between the costs, production volumes and profit to maximize it, forecast the financial results and develop a system of measures to end a supposed 
crisis. Analysis of the figures will help the management to see the real financial situation, establish its margins, investment attractiveness and creditworthiness.

Company managers make new managerial decisions, potential investors and creditors study the possibility of offering funds during the crisis, the tax body offers tax exemptions and vacations, the statistics bodies collect statistics to add to the macro level data to develop state measures based on the adjusted data of financial accounting and the balance sheet and the profit and loss account.

\section{CONCLUSIONS}

Our research demonstrated that to form an accounting (financial) report accurately one has to take into account an array of external factors. The spread of the dangerous disease and the quarantine imposed by the government to cushion the blow for the Russian economy had an impact on the financial statements by casting doubt over one of the key accounting principles, changing accounting both under Russian standards and under IAS. Additional costs and falling sales are the result of switching to remote work. They led to significant losses and a threat to financial stability of the company. The refusal to reduce oil production and a currency fall coupled with an oil price plunge triggered capital flight from the country, made resources more expensive and reduced production.

Changes in the basic indicators on the back of the aforementioned factors in different forms of accounting, such as falling revenues and net profit, a lower cost of assets and rising accounts receivable will have an utterly negative influence on the financial standing of companies. For instance, erroneous managerial decisions will lead to bankruptcy of many companies. The government mechanisms to prevent mass bankruptcies should be used - state subsidies, tax reliefs, credits for small and medium-sized business and many others. However, indirect support measures will not save the affected organizations in the long run, cash injections into the economy are necessary. Cash galore on the payment account of any company will help it cover all accumulated debt, boost investment attractiveness and higher competitiveness both on the domestic and foreign markets.

\section{REFERENCE LIST}

Aaronson, S. (2007) A match made in the corporate and public interest: Marrying voluntary CSR initiatives and the WTO. Journal of World Trade, vol. 41, p. 3-14.

Akhmadeev, R., Morozova, T., Voronkova, O. and Sitnov. A. (2019). Targets determination model for VAT risks mitigation at B2B marketplaces. Entrepreneurship and Sustainability Issues, vol. 7(2), p. 11971216.

Anantharaman, D. (2017) The role of specialists in financial reporting: Evidence from pension accounting. Review of Accounting Studies. vol. 22, p. 1261-1306.

Avvakumova, I.V., Bykanova, O.A. and Akhmadeev, R.G. (2020) Improvement of small business owners taxation. In the Proceedings of the 7th International Conference on Education and Social Sciences (INTCESS), p. 532-537.

Barbu, E. and Baker, R. (2010). A Historical and Neo-Institutional Analysis of Institutions Involved in International Accounting Convergence. Accounting and Management Information Systems, vol. 9(2), p. 218-241.

De George, E.T., Li, X. and Shivakumar, L. (2016) A review of the IFRS adoption literature. Review of Accounting Studies. vol. 21, p. 898-1004.

Golubtsova, E.V. and Zvereva, A.O. (2019) Expediency of parallel import legalization in Russian Federation. Proceedings of the 33rd International Business Information Management Association Conference, IBIMA 2019: Education Excellence and Innovation Management through Vision 2020, p. 782-787.

Gorlanov, S., Medelyaeva, Z., Malitskaya, V., Chirkova, M. and Kostyukova, E. (2019) Content analysis the term "effectiveness" and the concepts of its quantitative characteristics. Indo American Journal of Pharmaceutical Sciences. vol. 6 (3), p. 5293-5298.

Kevorkova, Z. A., Zhukova, G. S., Antonova, O., Dolbik-Vorobey, T. A. and Petrov A. M. (2020) Organizational prerequisites for transition to IFRS in the artificial intelligence context. Bulletin of the 
National Academy of Sciences of the Republic of Kazakhstan, vol. (384), p. 128 - 136.

Korableva, O., Durand, T., Kalimullina, O. and Stepanova, I. (2019). Studying user satisfaction with the MOOC platform interfaces using the example of coursera and open education platforms. Paper presented at the ACM International Conference Proceeding Series, p. 26-30. doi:10.1145/3322134.3322139

Maltseva, A., Shnyreva, E., Evreinova, E., and Avvakumova, I. (2020). The native language learning in the General education system of the Russian Federation. Amazonia Investiga, vol. 9(29), p. 347-358.

Morozova, T., Akhmadeev, R., Lehoux, L., Yumashev, A., Meshkova, G. and Lukiyanova, M. (2020). Crypto asset assessment models in financial reporting content typologies, Entrepreneurship and Sustainability Issues, vol. 7(3), p. 2196-2212.

Petrov, A. M. and Sembiyeva, L. M. (2020) Organizational and methodical mechanism of internal audit of settlements in corporate systems. Bulletin of the National Academy of Sciences of the Republic of Kazakhstan. vol.2 (384), p. $119-127$.

Petrova, G., Posadneva, E. and Morozova T. (2019) Leading the labour market by the law of supply and demand. Sustainable Leadership for Entrepreneurs and Academics. Springer Proceedings in Business and Economics. Springer, p. 263-271.

Singleton-Green, B. (2014) Should financial reporting reflect firms' business models? What accounting can learn from the economic theory of the firm. Journal of Management \& Governance. vol. 18, p.697-706

Ternovykh, K., Leonova, N., Malitskaya, V., Chirkova, M. and Markova, A. (2020) State and effectiveness of the Russian enterprise of horticulture production. International Transaction Journal of Engineering, Management \& Applied Sciences \$ Technologies, vol. 11 (6).

Voronova, T. A., Golubtsova, E., V., Maksimov, D. A., Novikova, E. S. and Ponomareva, N., V. (2020) The Role of Taxation in the Competitiveness of Russian Education Following Globalization and Digitalization Processes in the World Economy. Turismo Estudos \& Práticas, vol. 2, p. 1-7.

Voronova, T.A. and Novikova, E.S. (2019) Dynamics of Higher Education and Social and Economic Indicators Globally in Conditions of Digitalization Proceedings of the 34th International Business Information Management Association Conference, IBIMA 2019: Education Excellence and Management of Innovations through Sustainable Economic Competitive Advantage Vision 2025, p.1992-1999.

Zicke, J. and Kiy, F. (2017) The effects of accounting standards on the financial reporting properties of private firms: evidence from the German Accounting Law Modernization Act. Business Research. vol.10, p. 215-248.

Zvereva, A.O., Golubtsova, E.V. and Tsilikova, M.S. (2020) The specifics of the use of tax instruments in the digital trade of the Russian Federation. In the Proceedings of the 7th International Conference on Education and Social Sciences (INTCESS), p. 44-50. 